\title{
SELECTION INTO LABOR FORCE AND GENDER UNEMPLOYMENT GAPS
}

\section{Alena Bičáková}

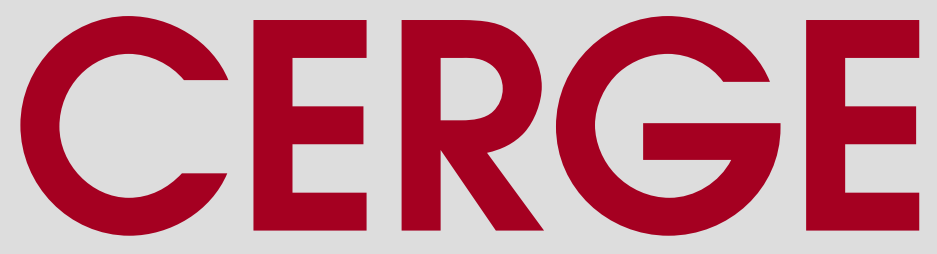

Charles University

Centerfor Economic Research and Graduate Education

Academy of Sciences of the Czech Republic

Economic Institute 


\title{
Working Paper Series 513 (ISSN 1211-3298)
}

\section{Selection into Labor Force and Gender Unemployment Gaps}

\author{
Alena Bičáková
}

CERGE-EI

Prague, June 2014 
ISBN 978-80-7343-317-8 (Univerzita Karlova. Centrum pro ekonomický výzkum a doktorské studium)

ISBN 978-80-7344-310-8 (Akademie věd České republiky. Národohospodářský ústav) 


\title{
Selection into Labor Force and Gender Unemployment Gaps*
}

\author{
Alena Bičáková
}

\author{
CERGE-EI ${ }^{\dagger}$
}

\begin{abstract}
This paper sets the groundwork for analysis of the effect of selection into labor force on gender unemployment gaps. We derive the Manski bounds for gender unemployment gaps in $21 \mathrm{EU}$ countries and show that in addition to the positive selection documented in the gender wage gap research, there is also evidence of negative selection into the labor force among women after childbirth. While positive selection of women into the labor force leads to downward bias in gender unemployment gaps, negative selection results in overestimation of gender unemployment gaps.
\end{abstract}

\begin{abstract}
Abstrakt
Tato studie vytváří rámec pro analýzu vlivu selekce do pracovní síly na genderové rozdíly v nezaměstnanosti. Nejdříve počítáme Manskiho hranice pro genderové mezery v nezaměstnanosti v 21 státech EU. Poté ukazujeme, že kromě pozitivní selekce, bežně dokumentované ve výzkumu genderových rozdílů v př́ijmech, existuje také negativní selekce žen do pracovní síly, a to v období po narození dítěte. Zatímco pozitivní selekce žen do pracovní síly vede k podhodnocování genderových mezer v nezaměstnanosti, negativní selekce tyto mezery naopak nadhodnocuje.
\end{abstract}

Keywords: Selection; Labor Force Participation; Gender Unemployment Gaps

JEL classification: J13, J21, J71

*I would like to thank Štěpán Jurajda and Nikolas Mittag for useful comments. This project was financially supported by the grant number P404/14/36154G from the Grant Agency of the Czech Republic.

${ }^{\dagger}$ CERGE-EI is a joint workplace of Charles University and the Economics Institute of the Academy of Sciences of the Czech Republic, Politickych veznu 7, 11121 Prague, Czech Republic. E-mail: alena.bicakova@cerge-ei.cz 


\section{Introduction}

Gender gaps in various labor market outcomes, such as wage, employment or unemployment, are widely used by researchers and policy makers to assess the relative position of women in the labor market. The size of gender gaps can be driven by three factors: gender differences in the outcome-relevant characteristics of those for whom the outcome is observable, gender differences in the returns to these characteristics, or gender differences in the selection of individuals into the state in which the outcome is observed.

While the impact of the first two factors is well understood and has been extensively quantified, the importance of selection has been, so far, only considered for gender differences in wages (e.g., Hunt (2002), Olivetti and Petrongolo (2008)). Under positive selection into employment, i.e. when factors that increase an individual's wage also enhance her likelihood of working, observed gender wage gaps under-estimate the gender wage gaps that would prevail if everyone were working. ${ }^{1}$ Olivetti and Petrongolo (2008) show that almost half of the negative relationship between the average gender wage gaps and the gender employment gaps documented for 14 OECD countries can be attributed to positive selection into employment.

Wages are observed only for those who work; (un)employment status is observed only for those who are in the labor force. One may expect the selection into the labor force to affect gender unemployment gaps in a similar way as selection into employment affects gender wage gaps. Under positive selection into the labor force, i.e., if labor force participants have a below-average propensity to be unemployed compared to non-participants, observed gender unemployment gaps will be underestimated relative to the gaps that would prevail if everyone were in the labor force. Similar to gender employment gaps and gender wage gaps, positive selection into labor force should result in a negative relationship between gender gaps in labor

\footnotetext{
${ }^{1}$ The implicit assumption is that male employment rates exceed female employment rates, which is a well-established empirical fact driven primarily by gender differences in labor force participation.
} 
force participation and gender unemployment gaps. ${ }^{2}$

In this paper we show that the effect of selection on gender unemployment gaps is more complex than conjectured above, as the labor force directly enters the definition of unemployment rates in gender unemployment gaps (in contrast with the effect of selection into employment on gender wage gaps). Gender differences in labor force participation may, therefore, result in gender unemployment gaps, even when the proportion of unemployed in the population is the same for both genders. This would, ceteris paribus, suggest that the larger the difference in the size of the population of men and women in the labor force, the greater the gender difference in unemployment rates, i.e. that there is a positive relationship between gender labor force participation gaps and gender unemployment gaps.

Figure 1, based on data for $21 \mathrm{EU}$ countries, ${ }^{3}$ reveals that the relationship between gender differences in labor force participation and gender unemployment gaps is indeed positive, with the coefficient of correlation equal to 0.42 and significant at the $5.7 \%$ confidence level, in contrast with the negative relationship (of a similar magnitude) documented in Olivetti and Petrongolo (2008) for employment and wage gaps. $^{4}$

The aim of this paper is to analyze the impact of selection into labor force on observed gender unemployment gaps. We derive the "worst case" or Manski bounds (Manski 1989; Manski 1990) for gender unemployment gaps under full labor force participation. Using the EU LFS data, we illustrate how taking the selection effect into account may alter the observed levels as well as the international comparisons

\footnotetext{
${ }^{2}$ From now onwards, we define the gaps as follows: gender labor force participation gap as male minus female labor force participation rate; and gender unemployment gap as female minus male unemployment rate.

${ }^{3}$ The data used in this note come from the 2007 EU LFS data. We focus on prime age individuals (between 25 and 54 years old). Detailed data description is available in Bicakova (2012). All aggregates are constructed using sampling weights. We use the standard International Labor Organization (ILO) definition of unemployment, which classifies as unemployed the individuals who have no job, have been actively looking for a job in the past four weeks, and are available to start working within two weeks.

${ }^{4}$ Figure 1 is similar to Figure 1 in Olivetti and Petrongolo (2008) in relating the extent of selection (the difference between the size of the selected samples of men and that of women) to the gender gap in the given labor market outcome, where gender wage gaps and gender unemployment gaps are defined so that positive values are favorable to men. When Greece is omitted from 1, the coefficient of correlation drops to 0.21 .
} 
Figure 1: Gender Differences in Unemployment and Labor Force Participation

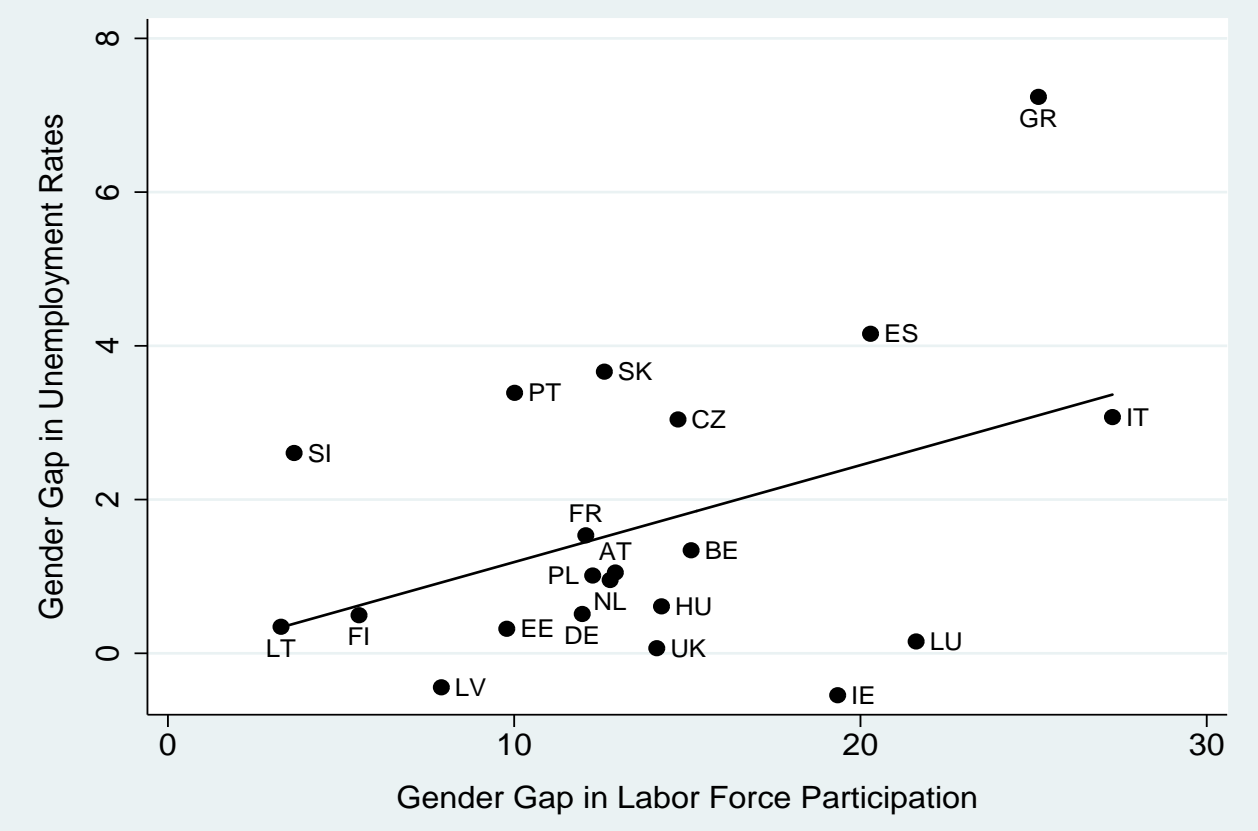

Note: EU LFS data in 2007, prime age individuals. The gender unemployment gaps are defined as the difference between female and male unemployment rates, and gender gaps in labor force participation as the difference between male and female labor force participation rates. Gaps are measure in p.p.

of gender differences in unemployment for 21 countries of the European Union. Last but not least, we provide evidence of negative selection into the labor force among women who take family leave after childbirth, which results in overestimation of gender unemployment gaps.

\section{Manski Bounds and the Selection Bias}

Gender unemployment gaps under full labor force participation are not observable (except when everyone participates in the labor market), but their magnitude can be bounded using the Manski bounds (Manski 1989; Manski 1990). We first derive the bounds for the overall unemployment rate and then extend them to gender unemployment gaps. The unemployment rate under full participation is equal to

$$
\operatorname{Pr}(U=1)=\operatorname{Pr}(U=1 \mid L F P=1) \operatorname{Pr}(L F P=1)+\operatorname{Pr}(U=1 \mid L F P=0) \operatorname{Pr}(L F P=0)
$$


where $\operatorname{Pr}(U=1 \mid L F P=1)$ is the observed unemployment rate, $\operatorname{Pr}(L F P=1)$ is the labor force participation rate, $\operatorname{Pr}(L F P=0)=1-\operatorname{Pr}(L F P=1)$ the non-participation rate, and $\operatorname{Pr}(U=1 \mid L F P=0)$ the unobservable counterfactual unemployment rate ('risk of unemployment') among non-participants if they were in the labor force. Using the fact that $\operatorname{Pr}(U=1 \mid L F P=0)$ is always bounded between 0 and 1, we can construct the lower and upper limits for $\operatorname{Pr}(U=1)$, while remaining agnostic about $\operatorname{Pr}(U=1 \mid L F P=0)$ :

$$
\begin{aligned}
\operatorname{Pr}(U=1 \mid L F P=1) \operatorname{Pr}(L F P=1) \leq \operatorname{Pr}(U=1) \leq \\
\operatorname{Pr}(U=1 \mid L F P=1) \operatorname{Pr}(L F P=1)+\operatorname{Pr}(L F P=0) .
\end{aligned}
$$

The Manski bounds for the unemployment rate under full participation have a straightforward interpretation and are equal to two alternative measures of joblessness. The lower bound, the product of the unemployment rate $\operatorname{Pr}(U=1 \mid L F P=1)$ and labor force participation rate $\operatorname{Pr}(L F P=1)$, is equal to the share of the unemployed in the population. The upper bound, the sum of the share of the unemployed in the population and the non-participation rate $\operatorname{Pr}(\operatorname{LFP}=0)$, is the non-employment rate. ${ }^{5}$ Using equation 1 for each gender separately $(f$ denotes women and $m$ men), the gender unemployment gap under full participation is bounded as follows

$$
\begin{gathered}
\operatorname{Pr}(U=1 \mid f, L F P=1) \operatorname{Pr}(\operatorname{LFP}=1 \mid f) \\
-\operatorname{Pr}(U=1 \mid m, L F P=1) \operatorname{Pr}(\operatorname{LFP}=1 \mid m)-\operatorname{Pr}(\operatorname{LFP}=0 \mid m) \\
\leq \operatorname{Pr}(U=1 \mid f)-\operatorname{Pr}(U=1 \mid m) \leq \\
\operatorname{Pr}(U=1 \mid f, L F P=1) \operatorname{Pr}(\operatorname{LFP}=1 \mid f)+\operatorname{Pr}(\operatorname{LFP}=0 \mid f)+ \\
\quad-\operatorname{Pr}(U=1 \mid m, L F P=1) \operatorname{Pr}(\operatorname{LFP}=1 \mid m)
\end{gathered}
$$

In particular, the gender unemployment gap reaches its maximum when the female unemployment rate under full participation attains its upper bound and the

\footnotetext{
${ }^{5}$ Note that the lower bound assumes employment as the counterfactual state of all the nonparticipants, whereas the upper bound assumes unemployment.
} 
corresponding male rate attains its lower bound; it reaches its minimum when the opposite is true. So the lower bound occurs when there is 'perfect' positive selection into the labor force for men (assigning unemployment to male non-participants as the counterfactual state) and 'perfect' negative selection into the labor force for women (assigning employment to female non-participants as the counterfactual state) and the upper bound occurs under the opposite scenario.

Restricting the nature of selection into the labor force and the counterfactual unemployment rates among women and men who are out of the labor force to be the same across gender $(\operatorname{Pr}(U=1 \mid m, L F P=0)=\operatorname{Pr}(U=1 \mid f, L F P=0))$ in the two extreme cases of perfect positive and perfect negative selection, the bounds for the gender unemployment gap under full participation narrow. Imposing these assumptions and taking into account the empirical fact that $\operatorname{Pr}(L F P=$ $0 \mid f)>\operatorname{Pr}(L F P=0 \mid m)$, the refined lower bound corresponds to the case when the counterfactual state of all female and male non-participants is employment and equals the gender gap in the shares of the unemployed in the population, while the refined upper bound assigns unemployment as the counterfactual state of the nonparticipants irrespective of gender and is equal to the gender gap in non-employment rates.

Figure 2 plots the observed gender unemployment gaps and the two sets of Manski bounds for the gender unemployment gaps under full participation in 21 EU countries in 2007. Countries are ranked by the observed gender unemployment gaps, marked with a circle. The lowest gender unemployment gaps in the EU are in the UK, Ireland, the Baltic States and Finland; the Mediterranean countries and the Czech and Slovak Republics are at the other end of the distribution.

The bounds show the limits of the potential selection bias in the observed gender unemployment gaps, i.e., the extent to which the observed gaps may underestimate or overestimate the 'selection-free' gender unemployment gaps under full participation. The direction of the bias depends on the nature of the selection and whether it differs by gender. The refined Manski bounds assume the selection into the labor 
Figure 2: Gender Unemployment Gaps and Their Manski Bounds across EU

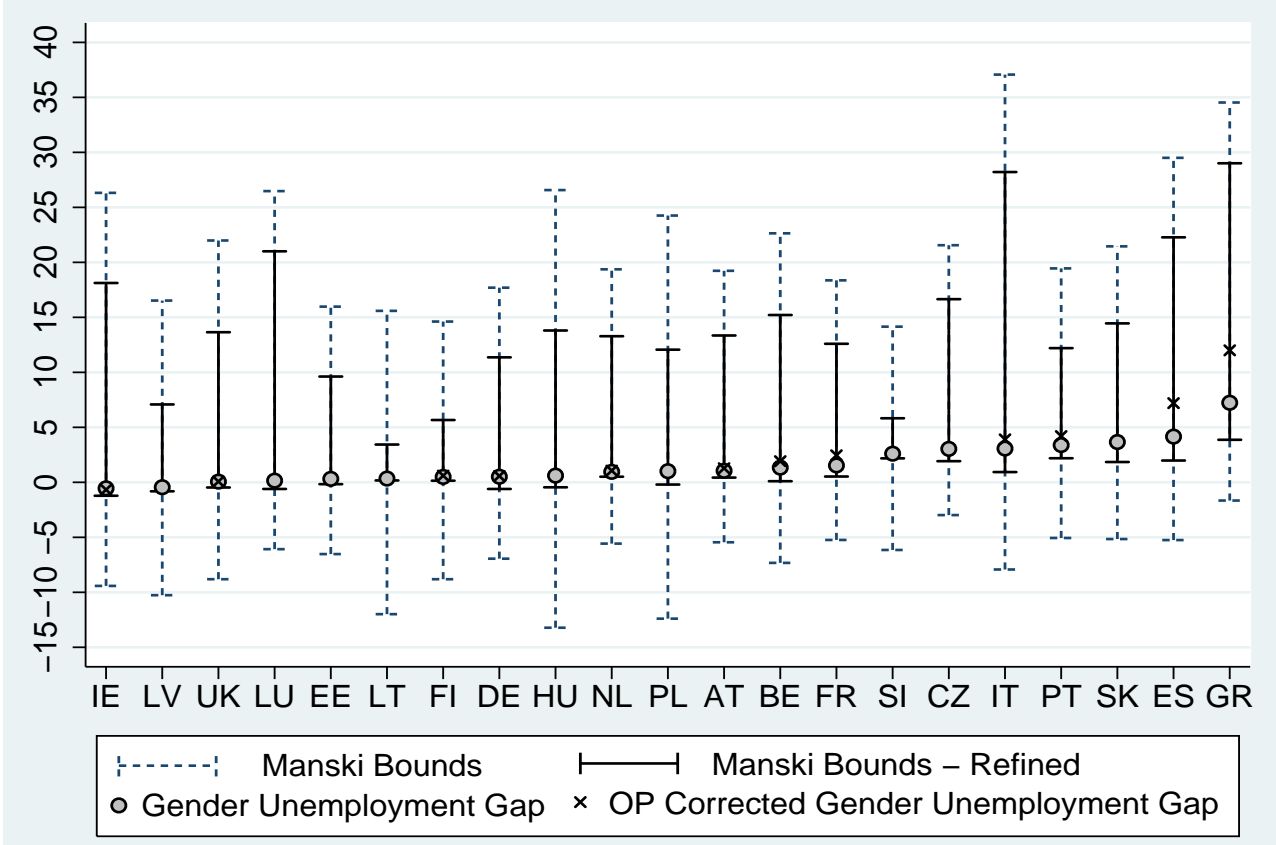

Note: EU LFS data in 2007, prime age individuals. Gender unemployment gaps are measured in p. p. as the differences between female and male unemployment rates. Refined Manski bounds correspond to the gender gap in the shares of the unemployed in the population and the gender gap in the non-employment rates respectively. The ' $x$ ' marks show the selection-corrected gaps assuming the same percentage bias as computed for gender wage gaps in Olivetti and Petrongolo (2008). Countries are ordered by the size of the observed gender unemployment gaps.

force to be the same for women and men. When there is positive selection into the labor force, the counterfactual unemployment rate among the non-participants exceeds the observed unemployment rate and the observed gender unemployment gaps underestimate the gender unemployment gaps under full participation. When there is negative selection into the labor force, the counterfactual unemployment rate among non-participants is lower than the observed unemployment rate among the participants and the observed gender unemployment gaps overestimate those under full participation. ${ }^{6}$ The distance between the observed gender unemployment gaps and the refined lower bound sets the limits for the bias driven by negative selection into the labor force, whereas the distance between the observed gender unemployment gaps and the refined upper bound sets the limits for the bias due to positive selection into the labor force.

Olivetti and Petrongolo (2008) construct the selection-corrected gender wage

\footnotetext{
${ }^{6}$ Section A.1 in the Appendix formalizes these statements.
} 
gaps for 13 West European countries and show that positive selection into employment leads to underestimation of gender wage gaps under full employment in countries with substantial gender differences in employment rates. We next simulate the selection-corrected gender unemployment gaps, assuming the same percentage bias as found Olivetti and Petrongolo (2008) for gender wage gaps. ${ }^{7}$ The OlivettiPetrongolo (OP) selection-corrected gender unemployment gaps, marked by ' $\mathrm{x}$ ' in Figure 2, indicate that while underestimation of gender unemployment gaps due to positive selection is likely in the Mediterranean countries, the size of the bias is much smaller than implied by either of the upper bounds.

Negative selection into the labor force goes against the evidence documented in the gender wage gap literature and has not been much discussed by previous research. There are, however, examples of a labor force withdrawal of individuals with below-average risk of unemployment, which results in negative selection into labor force. If a substantial number of employed women take job-protected family leave after childbirth, the female unemployment rate will increase solely due to the decrease in the size of the labor force. ${ }^{8}$ It has been found that in about half of EU countries, gender unemployment gaps exist only among individuals with children (Bicakova 2012). While the unemployment rates of women and men are the same for the childless, the unemployment rate among women with a child younger than 5 substantially exceeds that of comparable men. As the shares of the unemployed among women and men with a child below 5 are the same or very similar, the gender unemployment gap in this subpopulation is solely driven by the negative selection into the labor force, i.e. by positive selection of employed women into family leave. ${ }^{9}$ In what follows, we quantify the implications of negative selection of women into

\footnotetext{
${ }^{7}$ The ratios between the observed and the selection-corrected gender wage gaps are constructed from Table 2 in Olivetti and Petrongolo (2008), specifically, as the ratios between the observed median gender wage gaps in column 1 and the preferred estimates of the selection-corrected gaps in column 3.

${ }^{8}$ Similarly, if the typical duration of tertiary education is increased by one year, so that the majority of students graduate at the age of 26 rather than 25 , the observed unemployment rate among prime age individuals (25-54) will ceteris paribus go up simply due to the reduction in the size of the labor force, provided that the unemployment rate among tertiary level graduates is less than the average unemployment rate, which is a well-established stylized fact.

${ }^{9}$ See Bicakova (2012) for details.
} 
the labor force due to family leave for the observed gender unemployment gaps in the $21 \mathrm{EU}$ countries.

\section{Family Leave Bias in Gender Unemployment Gaps}

We calculate the impact of negative selection into labor force of women due to family leave on gender unemployment gaps in the $21 \mathrm{EU}$ countries by constructing the counterfactual gender unemployment gaps that treat a share of female nonparticipants with a child younger than 5, who are likely to return to the labor force by the time the child turns 10 , as employed. ${ }^{10}$ In the text, we also discuss consequences of assigning employment as the counterfactual state to all inactive women with a child younger than 5. Finally, we recognize that the counterfactual state of women on family leave is likely to change due to the negative impact of career interruption on human capital. However, as we focus only on the immediate selection effect due to the temporary labor force withdrawal, we abstract from any such causal effects. ${ }^{11}$ Figure 3 plots the counterfactual gender unemployment gaps, constructed as described above, next to the observed gender unemployment gaps. The difference between the two gaps shows the extent of the positive bias in the observed gender unemployment gaps induced by the labor force withdrawal after childbirth. Given our imputation rule, the level of the counterfactual gender unemployment gaps is always below that of the observed gender unemployment gaps. The extent of the bias, however, varies substantially across countries and alters their original ranking. In particular, the gender unemployment gaps are overestimated the most in the Central European and Baltic countries: by as much as

\footnotetext{
${ }^{10} \mathrm{We}$ construct this share as the difference between the labor force participation rate among women whose youngest child is between 5 and 10 and the labor force participation rate among women whose youngest child is below 5 . In this way, we take into account the fact that in some countries, in particular Mediterranean countries, many women permanently withdraw from the labor force after childbirth (Bicakova (2012)).

${ }^{11}$ As age is only available in 5-year intervals in the data, we cannot refine the counterfactual states on family leave by its duration, i.e. by the exact age of a child. Our simple imputation rule, however, is similar in spirit to that in gender wage gap literature (as in Olivetti and Petrongolo (2008)), where current counterfactual wage is typically constructed from the past wage observations, if available, rather than predicted in a way that would take into account the impact of the duration of the current career interruption.
} 
Figure 3: Observed and Counterfactual Gender Unemployment Gaps

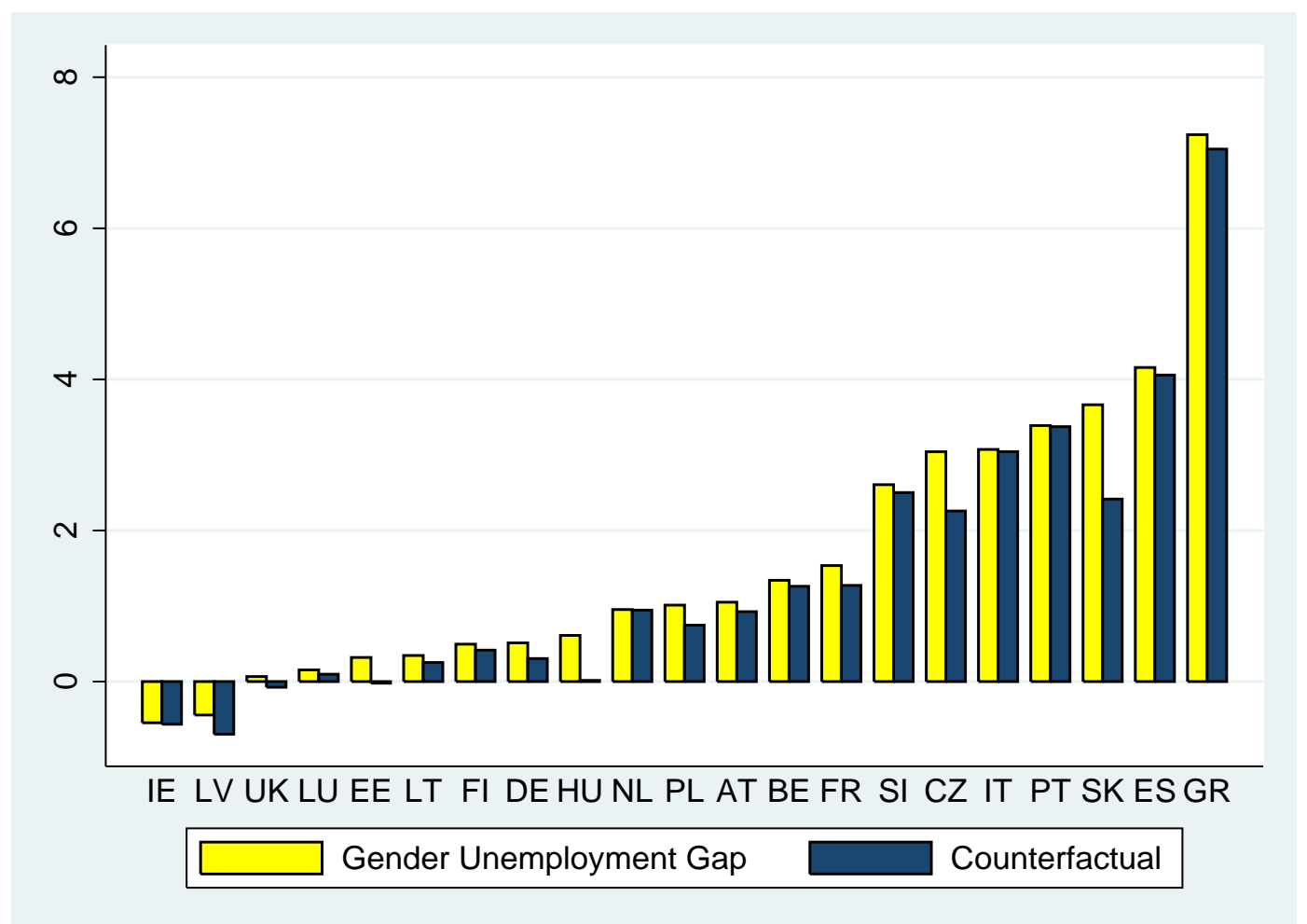

Note: EU LFS data in 2007, prime age individuals. Gender unemployment gaps are measured (in p.p.) as the differences between female and male unemployment rates. The counterfactual gender unemployment gaps treat the share of women with a child younger than 5, who are expected to return to the labor force within the next five years, as employed. Countries are ordered by the size of the observed gender unemployment gaps.

1.2 p.p. in Slovakia, 0.8 p.p. in the Czech Republic and 0.6 p.p. in Hungary. These are the countries characterized by high female labor force participation rate except in the period following a childbirth, when female participation drops substantially due to high take-up rate of very long (two or three years) paid family leave. When employment is assigned to all non-participating women with a child below 5 , irrespective of whether they are likely to return to the labor force, the counterfactual gender unemployment gaps overestimate the observed ones by at least 0.3 p.p. in 17 of the 21 countries. ${ }^{12}$ The bias is again the highest in Slovakia (1.5 p.p.) and in the Czech Republic and Hungary (1 p.p.). In addition, it is also close to 1 p.p. in Greece, Spain and Italy. The last three are, nevertheless, the countries, where many of the women who left the labor force after child birth never come back.

\footnotetext{
${ }^{12}$ Full results are available upon request.
} 


\section{Discussion}

This paper sets the groundwork for an analysis of the effect of selection into labor force on gender unemployment gaps. Previous literature has shown that gender wage gaps in countries with substantial gender employment gaps are underestimated due to positive selection of individuals into employment with respect to wages. While, by analogy, a positive selection into the labor force with respect to the risk of unemployment is likely and leads to a similar downward bias in gender unemployment gaps, we also point out the importance of negative selection into labor force. Institutions that tend to reduce the size of the labor force result in overestimation of the observed unemployment rates compared to unemployment rates under full participation. Provided these institutions affect women and men in different ways, they will lead to a positive bias in the observed gender unemployment gaps. We suggest that part of the observed cross-country variation in the gender unemployment gaps is driven by the differences in institutions that lead to different extent of the selection bias rather than by the genuine gender differences in the risk of unemployment. In particular, using the example of women withdrawing from the labor force after childbirth, we show that in countries with long family leave and high take-up rates, gender unemployment gaps are likely to be overestimated by about 1 percentage point.

Further research is needed to impute the counterfactual risk of unemployment to all the non-participants in order to construct the overall selection-corrected gender unemployment gaps as in Olivetti and Petrongolo (2008). ${ }^{13}$ A separate line of research could also focus on how the 'mechanical' selection-driven relationship between gender differences in labor force participation and gender unemployment gaps (considered here) interacts with the 'causal' channels between labor force participation and unemployment.

\footnotetext{
${ }^{13}$ Note, however, that the binary nature of our outcome variable does not permit any of the sample-selection correction methods based on the "position with respect to median" applied by Olivetti and Petrongolo (2008). The more traditional methods require either strong assumptions or convincing exclusion restrictions which we do not have in the data.
} 


\section{References}

Bicakova, A. 2012. "Gender Unemployment Gaps in the EU: Blame the Family." CERGE-EI Working Papers, no. wp475.

Hunt, J. 2002. "The Transition in East Germany: When Is a Ten-Point Fall in the Gender Wage Gap Bad News?" Journal of Labor Economics 20 (1): 148-169. Manski, Ch. F. 1989. "Anatomy of the Selection Problem." Journal of Human Resources 24 (3): 343-360.

—. 1990. "Nonparametric Bounds on Treatment Effects." American Economic Review 80 (2): 319-23.

Olivetti, C., and B. Petrongolo. 2008. "Unequal Pay or Unequal Employment? A Cross-Country Analysis of Gender Gaps." Journal of Labor Economics 26 (4): $621-654$.

Data Sources: European Commission, Eurostat, the 2008 release of the anonymised European Union Labor Force Survey datasets for the reference year 2007. We use Spring data to ensure comparability across years. The Eurostat has no responsibility for the results and conclusions presented in this paper.

\section{A Appendix: Derivation of the Impact of Selection}

\section{A.1 Stocks}

Denoting $E, U$, and $N$ the number of individuals who are employed, unemployed and out of the labor force (non-participants), unemployment rate under full participation can be written as $u^{*}=(1-n) \times u+n \times u^{C}$, a weighted average of the current unemployment rate $u=\frac{U}{E+U}$ and the counterfactual unemployment rate among the nonparticipants $u^{C}$, defined as the share of the nonparticipants who would have been unemployed (rather than employed) if in the labor force, and with weights determined by the share of individuals in and out of the labor force as given by the non-participation rate $n=\frac{N}{E+U+N}$. Non-random selection into labor force 
with respect to the unemployment risk arises whenever $u^{C} \neq u$. When there is positive selection into the labor force $\left(u^{C}>u\right), u$ underestimates $u^{*}$, when the selection is negative $\left(u^{C}<u\right)$, current unemployment rate overestimates the unemployment rate under full participation. ${ }^{14}$ As $n$ is greater for women than men, the female unemployment rate is affected by the selection effect more than the male unemployment rate. It follows that under positive selection into the labor force, gender unemployment gaps in countries with substantial gender differences in labor force participation will be underestimated relative to the case of full participation, under negative selection into labor force they will be overestimated.

\section{A.2 Flows}

When we focus on changes in labor force participation, i.e., flows rather than stocks, the nature of the selection is given by the labor market status of those who leave (or the average risk of unemployment among those who enter), relative to those who remain (already are) in the labor force. Following the example of women taking family leave, discussed in the text, let us consider a general situation in which a group of individuals leave the labor force. A change in the unemployment rate $u$ due to $\Delta N$ individuals leaving the labor force can be expressed as follows:

$$
\Delta u=\left(\frac{U-p \Delta N}{E+U-\Delta N}\right)-\left(\frac{U}{E+U}\right)=-\frac{\left(p-\frac{U}{E+U}\right) \Delta N}{E+U-\Delta N}
$$

where $p=\frac{\Delta U}{\Delta N}$ is the share of the unemployed among individuals who left the labor force, and $(1-p)$ is the fraction of previously employed individuals who left the labor force, specifically, $\Delta N=-(\Delta E+\Delta U)$ with $\Delta U=p \Delta N$ and $\Delta E=(1-p) \Delta N$. As a consequence, the lower Manski bound $\left(\frac{U}{E+U+N}\right)$ decreases by $\Delta u^{L B}=-\frac{p \Delta N}{E+U+N}$, and the upper Manski bound $\left(\frac{U+N}{E+U+N}\right)$ increases by $\Delta u^{U B}=\frac{(1-p) \Delta N}{E+U+N} \cdot{ }^{15}$

Comparison of $p$ with the initial unemployment rate $u=\frac{U}{E+U}$ indicates whether the $\Delta N$ individuals who left the labor force differed in their average risk of unemployment from those who stayed. ${ }^{16} p$ is smaller than $u$ in the case of negative selection, $p$ is greater than $u$ in the case of positive selection, and $p=u$ suggests that the

\footnotetext{
${ }^{14}$ Note that the two Manski bounds correspond to the two extreme cases of positive $\left(u^{C}=1\right)$ and negative $u^{C}=0$ selection into the labor force, where $u^{*}$ is the share of unemployed in the population and the non-employment rate respectively.

${ }^{15}$ Note that the effect on the share of the unemployed can never be positive, as labor force withdrawal can, if anything, only reduce the share of the unemployed in the population. On the other hand, the effect on the non-employment rate can never be negative, as labor force withdrawal can only either increase the numerator of the non-employment rate or leave it - when only unemployed individuals withdraw from the labor force - intact.

${ }^{16}$ Note that in the case of labor force withdrawal, the risk of unemployment of individuals who leave the labor force coincides with their previous labor market status, so that the nature of selection is determined by whether the share of the unemployed among those who leave the labor force is greater or smaller than the initial unemployment rate.
} 
selection of individuals into the labor force is random with respect to their risk of unemployment.

Table A.1 shows the size of the selection effect of a decrease in labor force participation by $\Delta N$ on the observed unemployment rate and the two Manski bounds under three extreme cases, $p=0, p=u$, and $p=1$, which correspond to negative, zero, and positive selection. ${ }^{17}$ While labor force withdrawal may increase, leave intact, or reduce the observed unemployment rate, it can only - if anything - decrease the lower Manski bound and/or increase the upper Manski bound, i.e. widen the interval for the unemployment rate under full participation. An increase in the labor force, on the other hand, has the opposite effect on all three measures and tightens the bounds for the unemployment rate under full participation.

Table A.1: Selection Effect of Labor Force Withdrawal of $\Delta N$

\begin{tabular}{|l|c|c|c|}
\hline Selection into Labor Force & $\Delta u$ & $\Delta u^{L B}$ & $\Delta u^{U B}$ \\
\hline$p=0$ (negative) & $+\left(\frac{U}{E+U}\right) \frac{\Delta N}{E+U-\Delta N}$ & 0 & $+\frac{\Delta N}{E+U+N}$ \\
\hline$p=u=\frac{U}{E+U}$ (zero) & 0 & $-\left(\frac{U}{E+U}\right) \frac{\Delta N}{E+U+N}$ & $+\frac{\left(1-\frac{U}{E+U}\right) \Delta N}{E+U+N}$ \\
\hline$p=1$ (positive) & $-\left(\frac{E}{E+U}\right) \frac{\Delta N}{E+U-\Delta N}$ & $-\frac{\Delta N}{E+U+N}$ & 0 \\
\hline
\end{tabular}

Note: The table shows the effect of a drop in the labor force by $\Delta N$ on the observed unemployment rate $\Delta u$ and on the lower and upper Manski bounds $\Delta u^{L B}$ and $\Delta u^{U B}$, depending on the nature of selection, as given by the initial labor market status of individuals who left the labor force: when all were previously employed $(p=0)$, when the share of those who were previously unemployed among those who left is the same as the share of the unemployed among those who stayed $p=u=\frac{U}{E+U}$, and when all were previously unemployed $p=1 . E, U$ and $N$ are the initial number of the employed, the unemployed and the nonparticipants.

Depending on the nature of the selection, the effect of changes in the labor force on the observed unemployment rate induces ceteris paribus the following relationships: Under negative selection into the labor force, a change in the labor force participation is negatively correlated with the change in the observed unemployment rate, uncorrelated or positively correlated with the change in the lower Manski bound, and negatively correlated with the change in the upper Manski bound. Under positive selection into the labor force, a change in the labor force participation is positively correlated with the change in the observed unemployment rate, as well as with the change in the lower Manski bound, but unrelated or negatively correlated

\footnotetext{
${ }^{17}$ Note that when $p$ lies between $\left(0, \frac{U}{E+U}\right)$, the size of the effect is between the effect under perfect negative selection $(p=0)$ and zero. Similar for the other cases that lie inbetween the rows of Table A.1.
} 
with the change in the upper Manski bound. Under no selection into labor force, the change in participation is correlated positively with the change in the lower Manski bound and negatively with the change in the upper Manski bound, while having no effect on the observed unemployment rate.

Note that the derived signs of the correlations under different types of selection also apply to the effect of selection on the observed unemployment rates due to cross-sectional, such as cross-country, variation in labor force participation in levels; focusing on stocks rather than flows, however, means that the nature of the selection is given by the average risk of unemployment among all the non-participants relative to those in the labor force.

Extending our results to the relationship between gender labor force participation gap and gender unemployment gap and ignoring cross-country differences in the labor force participation of men, ${ }^{18}$ we conclude that a positive selection of women into the labor force implies a negative relationship between the absolute value of the gender labor force participation gaps and gender unemployment gaps, whereas negative selection of women into the labor force implies a positive correlation. While this conclusion is similar to the stylized facts about the effect of selection on gender wage gaps, the positive correlation between the two measures presented in Figure 1 of the introduction can be only explained by the negative selection into labor force or may simply suggest that this relationship is driven by other causes than selection into labor force.

\footnotetext{
${ }^{18}$ Note that the coefficient of variation in labor force participation rates across the EU countries in 2007 for men (0.025) is less than one third of that for women (0.077).
} 


\section{Working Paper Series}

ISSN 1211-3298

Registration No. (Ministry of Culture): E 19443

Individual researchers, as well as the on-line and printed versions of the CERGE-EI Working Papers (including their dissemination) were supported from institutional support RVO 67985998 from Economics Institute of the ASCR, v. v. i.

Specific research support and/or other grants the researchers/publications benefited from are acknowledged at the beginning of the Paper.

(c) Alena Bičáková, 2014

All rights reserved. No part of this publication may be reproduced, stored in a retrieval system or transmitted in any form or by any means, electronic, mechanical or photocopying, recording, or otherwise without the prior permission of the publisher.

Published by

Charles University in Prague, Center for Economic Research and Graduate Education (CERGE) and

Economics Institute of the ASCR, v. v. i. (EI)

CERGE-El, Politických vězňů 7, 11121 Prague 1, tel.: +420 224005 153, Czech Republic.

Printed by CERGE-EI, Prague

Subscription: CERGE-EI homepage: http://www.cerge-ei.cz

Phone: + 420224005153

Email: office@cerge-ei.cz

Web: http://www.cerge-ei.cz

Editor: Marek Kapička

The paper is available online at http://www.cerge-ei.cz/publications/working_papers/.

ISBN 978-80-7343-317-8 (Univerzita Karlova. Centrum pro ekonomický výzkum a doktorské studium)

ISBN 978-80-7344-310-8 (Akademie věd České republiky. Národohospodářský ústav) 
CERGE-EI

P.O.BOX 882

Politických vězňů 7

11121 Praha 1

Czech Republic http://www.cerge-ei.cz 